\title{
Energy Resources as Factors of Geopolitical Importance of the Caspian Body of Water
}

\section{Jordanka Galeva}

\author{
Assistant professor, International Slavic University "G.R. Derzhavin"-Sveti Nikole, Republic of Macedonia \\ Email: dance.galeva@gmail.com
}

Doi:10.5901/mjss.2016.v7n5p151

\begin{abstract}
The purpose of this paper is to present a short introduction to the geopolitical importance and impact of energy resources on the definition of the legal status of Caspian body of water. The legal status of the water is regulated in accordance with international conventions or international law, and depends of the definition of water, as a sea or as a lake. The kind of water actually has a direct impact on the method of sharing of its natural resources. In the Caspian case, precisely because of its resources, (gas and oil), the issue of legal status is still open. In relation to this issue, research has shown that the position of five Caspian countries depends of their interest and benefits of the natural resources. The conclusion is that the energy resources are the primary factor for regulation of the legal status of Caspian body of water, whilst the pipeline network balances the world energetic stability.
\end{abstract}

Keywords: Caspian body of water, legal status, energy resources, geopolitics, network pipeline

\section{Introduction}

The Caspian region is well known for its bountiful and diverse flora and fauna, and also attractive due to its oil and gas reserves. These resources provide the region with a significant geopolitical importance, which also influences the classification of its waters (lake or sea) and the adoption of the most appropriate principle for the division of its natural resources. According to the definitions, a sea is defined as a body of water that is connected to other water flows and bodies of water, and is part of one of the world's oceans. ${ }^{1}$ Unlike the seas, lakes are defined as recess earth surface areas filled with water, without any linkages to the seas. These definitions are actually very important, when it comes to the definition of the legal status and the applications of the appropriate regulations that are necessary, in order to properly share the exploitation rights of the natural resources to be found in these waters, present on the seabed and in the sea or lake depths. Apart from the oil and gas deposits, the Caspian body of water is recognizable and attractive by its biological diversity and variant habitat, which contribute towards its diverse flora and fauna. Apart from the energy resources, the Osetra sturgeon and its various species, also provides a good base for the economic development of the region.

The main goal of this study are the energy resources generated by the waters in the Caspian region and their location as main factor for geopolitical attractiveness of the region as well as the pipeline network that balances the world energetic stability.

Considering the fact that the location and resources countries are basic geopolitical elements, this research focuses on the hypothesis that, besides location and resources, geopolitics is greatly influenced by the pipelines network that serve as instrument for balancing of powers.

The aim of the study is to show how the position of the countries, in the case Azerbaijan, Kazakhstan and Turkmenistan, prioritizes their position in signing treaties for construction of pipeline network that provides them and third parties energy stability, lower prices and less dependence on Russia.

Main questions the study answers are:

- How the legal status of Caspian waters affects the allocation of resources between the Caspian states?

- How the position of countries is important for the development of pipeline network?

- How the pipeline network contributes to the balancing of powers, i.e. ensuring energy security for the West and the East?

The research is based on a specific case study of the countries in the Caspian region and analytical, statistical and comparative methods were applied. International trades, such as the Convention on the Law of the Sea, statistics from

1 Depending on its location, a sea may be classified as marginal, if located between continents, inland if it is within a continent, continental shelf sea if adjacent to any of the continents and landlocked, if it stands alone, surrounded by land. 
the U.S. Energy Information Administration, monographs dealing with the issue, as well as reports from international meetings, were used as references.

\section{Caspian Sea or Lake?}

The Caspian body of water is surrounded by land belonging to five different countries and therefore it is considered to be a landlocked sea. It covers 371,000 square kilometers of Eurasian territories and it lies 28 meters below sea level, with a length of 1,190 kilometers and average width of 300 kilometers. The total length of the Caspian seashore is 7,000 kilometers; the average depth of its waters is 208 meters, with a maximum depth of up to 1,000 meters and water salinity of 0.1 to $13.7 \% \%^{2}$. The Caspian basin receives its waters from 130 different rivers, including the Volga, Ural, Tarek, Sulak, Samur and Kura. The single link to other seas is provided via the artificial navigable shipping canal, connecting the rivers Volga and Don at the smallest distance between the two. This canal is 101 kilometers long and provides a direct navigable link between the Caspian Sea and the Sea of Azov and thus the Black Sea. Namely, one of the basic questions of importance for the Caspian coastal countries is whether this is a sea or lake body of water. If it is a sea, considering its connection to the Black Sea via the artificial Volga-Don shipping canal, its waters would be divided at the national level and each country would have exclusive rights on its resources. For such regulation of the use of its waters, seabed or resources, one would apply the United Nations Convention on the Law of the Sea of Montego Bay3, enacted in 1982. According to the provisions of this Convention, the Caspian waters would be divided amongst the coastal countries and each one would get an exclusive right to exploit its resources within the breadth of its territorial sea, up to a limit not exceeding 12 nautical miles, as well as within the exclusive economic zone, whereby they would also be allowed to exploit the seabed and the subsoil. On the other hand, if the Caspian body of water is classified as a lake, one would apply the common law legal provisions, according to which, states would only get the 12 nautical miles sea distance as an exclusive economic zone, while for resource exploitation in the high seas, one would need to establish an international jurisdiction by all coastal states and provide for their joint approval. This is due to the fact that none of these countries has exclusive rights and the resources belong to them all and therefore should be divided into equal parts, i.e. $20 \%$ for each and every coastal state.

\section{Legal Framework}

Up to the dissolution of the Soviet Union, the navigation and free trade across the Caspian Sea, as well as the exclusive right of the Tsar's empire to own a naval fleet, were regulated on the basis of several agreements between the Russians and Persians, i.e. the Treaty of Resht (1729), the Treaty of Gulistan (1813) and the Treaty of Turkmenchay (1828). The breakup of the Russian empire in 1921 was followed by a friendship treaty for cooperation, followed by additional two new treaties. The first one on trade was signed in 1935 and the second one on trade and navigation in 1940, between the USSR and Iran, with an additional Annex, whereby the Caspian Sea is being defined as a Soviet and Iranian Sea. These treaties regulate the navigation issue and natural resources exploitation rights, which mainly relate to fishing, but do not define the blue (sea) borders.4 As a result of the dissolution of the Soviet Union and birth of new independent states, besides Iran and Russia, three more stakeholders emerged in the Caspian region: Kazakhstan, Azerbaijan and Turkmenistan. This also produced the dilemma of the appropriate division of exploitation rights of the natural resources present in this region and the question how much belongs to whom? As a result, there have been four Caspian Sea Summits organized during the last ten years, with the participation of the top leaders of the five countries that share its shores. The purpose of these summits was to find a long term solution to mark the waters and establish mutual cooperation in various sectors. The very first Caspian Sea Summit was held in April 2002 in Ashgabat (Turkmenistan); the second one in October 2007 in Tehran (Iran); the third one took place in November 2010 in Baku (Azerbaijan); and the fourth one in September 2014 in Astrakhan (Russia). These meetings were used to discuss the future cooperation and partnership strategies, based on joint responsibility, on various issues related to mining rights, navigation and strengthening of the economic cooperation; about foreign influences and interest about the region and territorial issues; regarding the oil deposits that have been estimated to 18 billion tons, i.e. between 70 and 200 billion barrels of oil, which

\footnotetext{
2 Mar Caspio, Treccani Enciclopedia online, http://www.treccani.it/enciclopedia/mar-caspio/ (12.04.2016)

3 United Nations Convention on the Law of the Sea, http://www.un.org/depts/los/convention_agreements/texts/unclos/unclos_e.pdf (20.04.2016)

${ }^{4}$ Lorena di Placido, (2010) II bacino di Mar Caspio, Situazione, tendenze e criticità nel cuore energetico dell'Euroasia, Rivista Marittima; http://www.marina.difesa.it/conosciamoci/editoria/marivista/Documents/2010/03_mar/DiPlacido.pdf (25.04.2016)
} 
would account for around 10\% of the world wide reserves. In addition, several important documents have been signed during these summits, such as: the Statement on the sovereign rights to the natural resources of the Caspian Sea; Joint Statement and Agreement on cooperation in the field of security at the Caspian Sea, with a commitment to fight against terrorism, organized crime, trafficking of weapons, human beings, drugs etc.; as well as bilateral agreements signed between Russia, Azerbaijan and Kazakhstan on marking of international borders, rights of the countries and obligations towards third parties. Nevertheless, what is still missing is some sort of a multilateral document that would precisely establish the borders along the Caspian Sea and officially define them as either sea or lake borders. This shortcoming is directly linked to the energy resources, which are bountiful and make this region very attractive and important for geopolitical reasons.

\section{Energy Resources and Interests of the Countries in the Caspian Region}

As early as in the 19-th Century, oil has been the driving force behind the growth of production and trade in this region. The very first individuals who became aware of the potential and importance of this region and hence showed interest for it were the Nobel brothers, followed by the Rothschild family, whilst Brothers Nobel, Royal Dutch Shell and Oil were the very first companies that started pumping oil. ${ }^{5}$ The available data about this period shows that in $1897,45 \%$ of the entire oil produced in the world, was produced in the Baku region and that Russia, thanks to this region, was the leader in oil production during the 1898-1902 period. In comparison, at the time of dissolution of the USSR, the oil produced in this region accounted for only $3 \%$ of the total world production, with the largest quantities originating from Azerbaijan. Nevertheless, regardless of these percentage figures registered during the early 1990-ies, the today's reserves at the bottom of the Caspian Sea have been estimated at around 75 billion barrels of oil, 6.9 trillion cubic meters of gas and $90 \%$ of all Osetra sturgeon species in the world, which provides much of the world's caviar. As already mentioned, these waters have not yet been universally defined, and people who consider them as Caspian Lake, expect for a mutual agreement to be achieved with respect to the international borders, whereas the Caspian Sea alternative would require borders that would conform to a median line equidistant from the shores of the neighboring nation-states.

The Russian stands with regards to the legal status of the Caspian body of water, requires adoption of a separate regulation, i.e. thus providing it with a status of a landlocked sea and division of the subsoil for the purpose of energy resources exploitation, with free use of its waters as a common good. Russia started to gradually implement this idea in practice, by signing bilateral and trilateral agreements with its neighboring countries of Azerbaijan and Kazakhstan, for international division of the Caspian Sea according to the equidistant median line principle. Nevertheless, despite the dissolution of the Soviet Union, Russia has maintained its dominance in the region. Russia heads the world's list of countries with the largest reserves of natural gas; it is the second producer of gas in the world, after the USA; and it is third in the world when it comes to energy production and spending. Oil and natural gas account for $30 \%$ of the Gross Domestic Product and $60 \%$ of the exports, with $85 \%$ of the exported gas destined for the European market (or $94 \%$ if one includes exports to Turkey). Quantity wise, this would mean a daily production of around 180 Giga cubic meters gas and 7.3 million barrels of oil (data registered in 2009), out of which $80 \%$ are destined for the European market, $12 \%$ for the countries in Asia and 3.5\% for the USA. ${ }^{6}$ With respect to the Caspian region, the goal for the Russians is to maintain the monopoly over the Caspian gas, especially the production in the eastern part of the Caspian region, i.e. in Turkmenistan and Kazakhstan and maintain the stronghold of some of its users, having in mind the recent competition originating from Azerbaijan.

Namely, the Azerbaijan's economy is based and to a large extent depends on its energy resources, with the export of raw materials and gas, accounting for $95 \%$ of its total exports ${ }^{7}$. Since 1994, Azerbaijan has been entering into agreements with the foreign companies for the exploitation of its offshore energy resources, with around $80 \%$ of the oil being produced on the offshore oil fields located outside the national territorial waters, i.e. more than 12 miles offshore, and thus, the Azerbaijanis tend to prefer international law. Besides the dissolution of the former USSR, having in mind the division of the Caspian soviet waters into 4 exclusive economic zones back in 1970, Azerbaijan supports the idea of dividing the Caspian Sea into 5 national sectors, according to the equidistant median line principle. With such a division, the Azerbaijani waters would include not just the offshore oil fields, but also the ones along the border lines. Unlike

\footnotetext{
${ }_{5}^{5}$ Petrolio e geopolitica nel bacino del Mar Caspio, Volume IV / Economia, politica, diritto degli idrocarburi http://www.treccani.it/portale/ opencms/handle404?exporturi=/export/sites/default/Portale/sito/altre_aree/Tecnologia_e_Scienze_applicate/enciclopedia/italiano_vol_4/ 423-430_x8.2x_ita.pdf (24.04.2016)

${ }^{6}$ Treccani Atlante geopolitico 2014, (2015) Istituto della enciclopedia italiana, Roma, p.725.

7 U.S. Energy Information Administration, https://www.eia.gov/beta/international/analysis.cfm?iso=AZE (10.05.2016)
} 
Russia, which has already signed bilateral agreements for the distribution of the seabed subsoil with Azerbaijan and Kazakhstan, Iran is against such a policy, a position that is further enhanced by the dispute between Iran and Azerbaijan, regarding the ownership of the Araz-Alov-Sharg oil field along the border.

The total length of the Iranian shoreline is 740 kilometers and its problem with defining the borders is caused by the convex shape of its Caspian Sea shoreline. If this body of water is considered to be a landlocked sea, then Iran would control $12 \%$ of the waters, and if it is classified as a lake, Iran would get an additional $2 \%$ under its control. What really plays into the favor of Iran is the proposal for national division of the waters in equal parts (condominium ${ }^{8}$ ), pursuant to which, each country would control $20 \%$ of the waters. Although Iran is the fourth country in the world, when it comes to its oil reserves, with 157 billion barrels and ranks sixth in the world according to its daily production, with 4,1 million barrels and holds the third spot in production of natural gas, immediately following the USA and Russia ${ }^{9}$, still, it is not willing to give up the resources in the Caspian region, especially the parts that are very close to the territorial waters and more plentiful in comparison with the parts that are within the national territorial waters. As a result, Iran is mainly interested in maintaining a status quo policy, and if the choice is to be made between a sea and a lake, the "lake" option would allow Iran to use a larger portion of the surface and seabed and provide access to some areas that would not be allowed otherwise. However, in this case, the Iranian proposal envisages division of water and seabed in equal parts between littoral states. Worldwide, as already mentioned, although Iran has, produces and exports large quantities of oil (mainly to China and Japan), it also imports oil derivatives (such as petrol) and gas (mainly from Turkmenistan), due to the very limited capacity of its refineries, which hardly meets the demand. ${ }^{10}$

Kazakhstan has the same problem with the low capacity of its refineries. In 2013, Kazakhstan has produced 81.8 million tons of crude oil and 42.3 billion cubic meters of gas, whilst it is capable of refining only 14.3 million tons of oil. Nevertheless, considering the entire data on crude oil production, which has tripled during the last twenty years, Kazakhstan is amongst the top 15 oil producers and top 20 gas producers in the world. ${ }^{11}$ Thanks to such quantities of energy resources, from the very beginning, Kazakhstan was successful in attracting the largest oil companies such as Eni, BP, Shell, Chevron, Total and Lukoil. ${ }^{12}$ With regards to the issue of the legal status of the Caspian body of water, Kazakhstan has the longest shoreline, with almost 1,900 kilometers, which, if one were to divide the waters pursuant to international sea, would bring Kazakhstan the largest piece of the "cake" of 29.5\%. While expecting a final solution, it reached an agreement with Russia in 1998 to draw a median line to divide the seabed, and hence divide the subsoil resources in the Caspian region (19\% to Russia and 27\% to Kazakhstan), and at the Ashgabat Summit in 2002, Kazakhstan signed a Protocol with Russia, which precisely defined the sovereignty of the nearby oil fields of Kurmangazy, which now belongs to Kazakhstan, and the fields of Tsentral'noe and Khvalynskoe, which now belong to Russia. $^{13}$

Unlike Kazakhstan, after acquiring its independence back in 1991, Turkmenistan was neutral until 2007, when it opened a dialogue for cooperation at the regional and international level. The basic economic resource of the country are its oil and gas reserves, and it is estimated that $11.7 \%$ of the overall gas reserves in the world, or 24.3 trillion cubic meters are to be found on Turkmenistan's territory. Up to 2009, Turkmenistan was the largest exporter of gas amongst the neighboring countries (mainly to Russia and Iran), thanks to the low prices, i.e. limited infrastructures; however, at the end of 2009 the situation has changed with the Chinese entry on the Turkmenistan market and the construction of the Central Asia-China Gas Pipeline, connecting Turkmenistan and China. With respect to the legal status of the Caspian body of water, Turkmenistan believes that the equidistant median line principle should be applied, by connecting the medium points of the shoreline segments at the opposite side, which would be very beneficial for Turkmenistan and to the detriment of Azerbaijan. Namely, the disputes between the two countries are related to the borderline oil fields of KyapazSerdar, Azeri-Omar and Chirag-Osman. Since the distance between their shoreline is less than 400 miles, the conventional limits of Exclusive Economic Zone (up to 200 miles from the shoreline), cannot be applied and therefore a median line should be drawn to mark the share of each side.

\footnotetext{
8 Joint sovereignty, especially joint rule of territory by two or more nations, or a plan to achive it.

${ }^{9} \mathrm{https}: / /$ www.eia.gov (10.05.2016)

10 Treccani Atlante geopolitico, Op.cit., p. 472-3.

11 https://www.eia.gov (10.05.2016)

${ }_{12}$ Atlante Geopolitico, Op.Cit., p.497.

${ }_{13}$ Paolo Sorbello, (2011) La geopolitica dell'energia virtuale, Euroasia, Rivista di studi geopolitici http://www.eurasia-rivista.org/lageopolitica-dellenergia-virtuale/10648/. (25.04.2016)
} 


\section{Division of the Caspian Water and Pipeline Network}

The geopolitical importance based on energy resources, is the main reason for the ongoing legal cases of these waters, which would also affect the development of the national economies. The question is how the legal status of Caspian waters affects the allocation of resources between the Caspian states? In the text above, we have already discussed the various states' interests for division, pursuant to the scenarios of a landlocked sea, international lake and condominium principle. The condominium principle, which was proposed and supported only by Iran, provides for an equal share of the waters for each country, i.e. $20 \%$. The landlocked sea division principle is most favorable to the states with the longest shorelines, i.e. Kazakhstan with 1,884 km and Turkmenistan with 1,768 km, which would get control over 29.5\% and 27\% of the sea respectively. This division is not favorable to Azerbaijan, which has the shortest shoreline of $713 \mathrm{~km}$ and Iran with $740 \mathrm{~km}$, which would assume national control of only $11 \%$ and $12 \%$ of the waters respectively. In such an event, Russia would get $20 \%$ of the Caspian waters, i.e. the same percentage as per the condominium option, or just $1 \%$ more than if one would apply the lake waters principle.

In comparison with the sea approach, the division according to the lake waters principle would be more favorable to Azerbaijan, (which would get $18 \%$ instead of $11 \%$ of the waters), and to Iran (which would get $14 \%$ instead of $12 \%$ ) but still less in comparison with the share to be acquired by the condominium principle. ${ }^{14}$ According to the median line, the division is already done. Namely, Russia, Kazakhstan and Azerbaijan get 19\%, 27\% and 18\% respectively of total $64 \%$ Caspian water, but this principle of division is not yet accepted by Iran and Turkmenistan, because of the dispute with Azerbaijan with regards to Araz-Alov-Sharq and Kapaz/Sardar offshore sites. These issues were already raised as a topic at several conferences and the next one is expected to be held in September 2016.

The figure below (on the left) shows: territorial border agreed by Russia, Azerbaijan and Kazakhstan (medium line), by Iran (condominium) and according to Turkmenistan (connecting the medium points of the shoreline segments at the opposite side), and (on the right) shows the major Caspian and natural gas export routes.

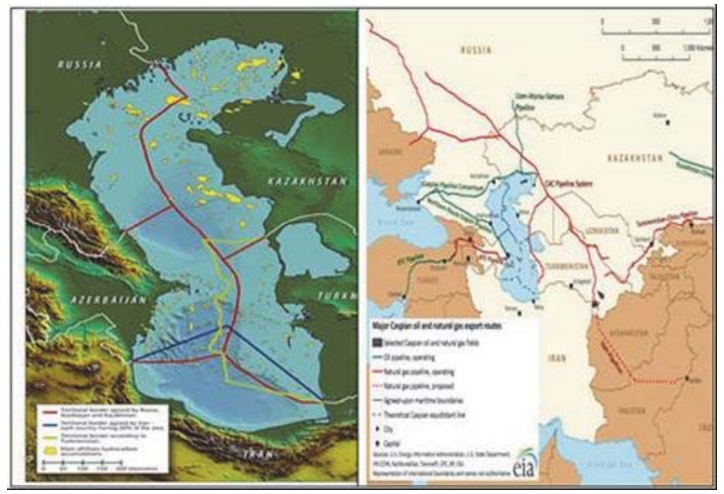

Font: https://www.geoexpro.com/magazine/vol-10-no-515.

http://www.eia.gov/beta/international/regions-topics.cfm?RegionTopiclD=CSR

The other significance of the energy resources as a driving force for the region is related to transport. As I already mentioned, besides location and resources, geopolitics is greatly influenced by the pipelines network that serve as instrument for balancing of powers.

Nevertheless, despite the dissolution of the Soviet Union, Russia has maintained its dominance in the region, both with respect to energy resources and transport network, but also when it comes to leadership in establishing new political and economic alliances. The Russian interest for marine alternative is mostly led by the interest to block the construction of offshore projects and retain monopoly on the pipeline network. Several pipeline networks pass through Russia such as Northern Early Oil Pipeline (for the oil transport from Baku to Novorossisysk on the Black Sea), part of Central Asia where

${ }^{14}$ Central intelligence agency, https://www.cia.gov/library/publications/resources/the-world-factbook/fields/print_2060.html (10.05.2016)

15 Petrov E., Ameline N., (2015) Geology without limits, in Geoexpro, The favorite petroleum geosciences magazine, vol.10, Num.5, p.29. (Online) Available: http://assets.geoexpro.com/uploads/fb83ded7-634e-4a03-92b4-5e213a94e9e0/GEO_ExPro_v10i5_Full.pdf (14.05.2016) 
center gas pipeline system runs from Turkmenistan via Uzbekistan and Kazakhstan to Russia and major portion of the Kazakhstani oil is directed towards the Russian oil pipelines leading to the Black Sea, whilst a portion of the crude oil is shipped across the Caspian Sea to Baku and via BTC to the Mediterranean.

Thanks to its resources, geographic location and the good infrastructure (the oil pipeline BTC [Baku-TbilisiCeyhan], the gas pipeline-South Caucasus Pipeline [SCP], known as BTE [Baku-Tbilisi-Erzerum], the gas Trans Adriatic Pipeline [TAP], Gazi-Magomed-Mozdok Pipeline), Azerbaijan has become a central hub for the East-West energy corridor, which provides for avoidance of the Russian routes to the north and the Iranian ones to the south. ${ }^{16}$ However, Iran has also established agreements to export natural gas via planned regional pipelines as Iran-Iraq pipeline, IranOman pipeline and Iran-Pakistan pipeline and has the potential to become an important gas supplier to its region. Turkmenistan form other hand is attractive due to its geographic location and therefore it is part of the TAPI projects, linking it with Afghanistan, Pakistan and India, the Trans-Caspian Gas Pipeline (TCGP), linking it to Azerbaijan and the West ${ }^{17}$ and also Turkmenistan-China gas pipeline, runs from Turkmenistan, enters Uzbekistan, crosses KazakhstanChina border and connects to the West-East Gas Pipeline ${ }^{18}$.

The question is how these pipeline networks contribute towards balancing of powers, i.e. ensuring energy for both the West and East?

Namely, the development of the pipeline network is the main tool for the international participation and balancing of the energy stability. The fear of unilateral dependence on Russian monopoly on the delivery of energy resources encourages other countries to start consortiums and invest in pipeline networks that aim to balance the energy dependence. Construction of such pipelines with support from Western countries, mainly in Azerbaijan, Georgia and Turkey through the Black and Mediterranean Sea for delivering gas in the West, as well as the Chinese investments in Kazakhstan and Turkmenistan for delivery on the East, clearly shows how Russia and Iran can be bypassed. Despite China, who is in this region, the support comes also from the United States that supports the construction of TAPI, with the aim to delay the Iranian project IME and to exclude Iran from the international relations.

\section{Conclusion}

All the above said can lead to the conclusion that Azerbaijan, although the smallest in the region, good located and backed by its good infrastructure (energy pipelines, rail and sea transport) is becoming main and direct competitor of Russia in the battle for European markets. It can be considered as a buffer zone between Iran and Russia which can be perceived as ideal alternative bridge to the West. On the other side, Kazakhstan, which borders with China, and Turkmenistan, represents the new bridge to the East. Turkmenistan used to depend on Russia in the past, precisely due to the scarce infrastructure, but with time, it became attractive for some foreign partners like China. In fact, today, Turkmenistan and Kazakhstan are directly involved delivering Caspian oil to East Asian market.

The analysis of the Caspian area, as geopolitical region, shows how the geographic location of the Caspian region countries and the abundant energy resources of the Caspian Sea, provide this region with an enormous international geopolitical significance. The analysis shows how the interests of great powers interact therefore and that the pipeline network represents the new factors for balance of authorities. The choice of energy resources, as a subject of the research, arises from the relevance and importance of the issue and contributes to the process of updating the current information on energy security. Besides the fact that energy resources have a direct impact on international regulations, they are also a key factor for the development of infrastructural networks. The pipeline network of alternatives play major role in this game and the study can serve for further analysis in other similar study cases.

\section{References}

Di Placido L., (2010), II bacino di Mar Caspio, Situazione, tendenze e criticità nel cuore energetico dell'Euroasia, Rivista Marittima, (Online) Available: http://www.marina.difesa.it/conosciamoci/editoria/marivista/Documents/2010/03_mar/DiPlacido.pdf (25.04. 2016)

Jean Carlo. Geopolitica del mondo contemporaneo, Editori Laterza, Bari, 2012

Central intelligence agency, https://www.cia.gov (Online) Available (10.05.2016)

Petrov E., Ameline N., (2015) Geology without limits, Geoexpro, The favorite petroleum geosciences magazine, vol.10, Num.5, (Online) Available: http://assets.geoexpro.com/uploads/fb83ded7-634e-4a03-92b4-5e213a94e9e0/GEO_ExPro_v10i5_Full.pdf (14.05.

\footnotetext{
16 Idem; Treccani Atlante geopolitico, Op.cit., p.212-213;

${ }_{17}$ Atlante Geopolitico, Op.cit., p.880.

${ }^{18} \mathrm{https} / / / w w w . e i a . g o v$
} 
2016)

Petrovic Dragan, Geopolitika postsovjetskog prostora, Promotej, Novi Sad

Sorbello P., (2011) La geopolitica dell'energia virtuale, Euroasia, Rivista di studi Geopolitici, (Online) Available: http://www.eurasiarivista.org/la-geopolitica-dellenergia-virtuale/10648/ (25.04.2016)

Mar Caspio, Treccani Enciclopedia online, (Online) Available: http://www.treccani.itenciclopedia/mar-caspio/ (12.04.2016)

Petrolio e geopolitica nel bacino del Mar Caspio, Volume IV / Economia, politica, diritto degli idrocarburi (Online) Available: http://www.treccani.it/portale/opencms/handle404?exporturi=/export/sites/default/Portale/sito/altre_aree/Tecnologia_e_Scienze_a pplicate/enciclopedia/italiano_vol_4/423-430_x8.2x_ita.pdf (24.04.2016).

R.H. Rair Dekmejian, Hovann H. Simonian, I.B. Tauris, New York, 2003

Treccani Atlante geopolitico 2014, Istituto della enciclopedia italiana, Roma , 2015

United Nations Convention on the Law of the Sea; http://www.un.org/depts/los/convention_agreements/texts/unclos/unclos_e.pdf (Online) Available (20.04.2016)

U.S. Energy Information Administration, https://www.eia.gov/beta/international/analysis.cfm?iso=AZE (Online) Available (10.05.2016) 